Oliver Carter, Birmingham Centre for Media and Cultural Research, Birmingham City University. oliver.carter@bcu.ac.uk

www.alteconomies.com

\title{
Biography
}

Dr. Oliver Carter is a senior lecturer in media and cultural theory at the Birmingham Centre for Media and Cultural Research, Birmingham City University. His research focuses on alternative economies of cultural production; informal forms of industry that are often removed from a formal cultural industries discourse. He is the author of the forthcoming monograph Making European Cult Cinema: Fan Enterprise in an Alternative Economy, published in 2018 by Amsterdam University Press. He is currently working on his latest book, which investigates the development of the British hardcore pornography business. The research for this publication informs the forthcoming documentary Hardcore Guaranteed: The Mike Freeman Story (Simon Fletcher 2018). You can out more about Oliver's work by visiting www.alteconomies.com. 


\section{Original Climax Films: Historicising the British Hardcore Pornography Film Business}

This article presents findings from my research into the British hardcore pornography business. Porn studies has given little coverage to the British pornography business, with much of the academic literature focusing on the American adult entertainment industry. Recently, there has been a rising interest in the historical framework of porn cinemas in both popular culture, and in academic work.

This article contributes to this debate, taking both a cultural and economic approach to explore the conditions that led to the emergence of British hardcore production as an alternative economy in the 1960s. In this economy entrepreneurs make use of new technologies to produce artefacts that are exchanged for an economic benefit, while circumventing laws to distribute their artefacts. To historicise this economy, I draw on ethnohistorical research, which includes interviews with people involved in the British hardcore business, and archival research.

I argue that a combination of glamour film making, a relaxation of political and cultural attitudes towards sexuality, the location of Soho, London, and emerging technologies for producing films collectively contribute to the emergence of an alternative economy of British hardcore production. I focus specifically on the practices of two entrepreneurs within this economy, Ivor Cook and Mike Freeman, considering how their actions inadvertently created the British hardcore film business, and played a significant role in the development of hardcore production outside of the UK.

Key Words: British pornography, Ethnohistory, Political Economy, Enterprise, Technology.

\section{'No Sex Please, We're British'}

Over the past several years, there has been a renewed interest in the historical foundations of adult entertainment. David Simon's HBO television series The Deuce premiered in 2017, which focuses on the birth of the American hardcore porn business in New York, while Amazon Studios released American Playboy: The Hugh Hefner Story to their Prime streaming platform the same year. A number of studies have recently appeared that explore the history of the American hardcore pornography industry (Heffernan, 2015; Alilunas, 2016; Church, 2016; Tarrant, 2016). Many of these works give attention to the relationship pornography has with technology and economics. As Heffernan $(2015,38)$ recognises, earlier academic studies of hardcore pornography neglected to place "economics at centre stage in the historical narrative". Outside of the United States, little recognition has been given to the histories of other national porn cinemas. An exception to this is the work of Giovanna Maina and Federico Zecca (2014) on the birth of the Italian porn film industry, and Mariah Larsson's (2016) examination of the conditions that led to the development of Sweden's industry. In comparison, British pornography has surprisingly received little academic attention.

The majority of work that discusses the British pornography is by non-academics. These studies have provided a foundation for this article, identifying key names and dates, and have also been helpful contacts. However, there is a lack of depth. For example, Simon Sheridan (2005) and David McGillivray (2017) tend to situate British hardcore pornography film making alongside the British sex softcore sex film. Others place British hardcore amongst the wider phenomenon of hardcore cinema. Hebditch and Anning (1988) occasionally discuss the clandestine nature of British pornographic film production, conducting interviews with a number of key producers from the period, such as Mike Freeman, Lasse Braun, and Hans Moser as part of their investigation into national pornography industries. David Flint (1999, 95 - 116) gives a historical chapter on the development of 
British pornography, and Dave Thompson (2007) offers a chapter on 8mm British stag films, reviewing a small sample from the 1960s and 1970s, but reveals little about how they were produced or distributed. Journalist Martin Tomkinson (1982) summarises his investigation into London's Soho pornography business, but focuses more on pornographic magazines of the 1970s, while fellow journalists Barry Cox, John Shirley and Martin Short (1977) discuss how the London Metropolitan Police colluded with Soho pornographers to make money; this resulted in efforts to eradicate police corruption in the force.

In academic literature, one can find mentions of the British pornography industry in the work of I.Q Hunter (2013, 116 - 122), who draws on interviews with Mike Freeman and Lindsay Honey when briefly discussing the place of hardcore production within wider British 'trash' cinema. Similarly, Steve Chibnall (2003, 45 -47) contrasts elements of the film Get Carter (Mike Hodges, 1971) with the British hardcore pornography business. Over the course of three pages, Chibnall identifies some of the main players in the business, such as Ivor Cook, Evan 'Big Jeff' Phillips, John Lindsay, and George Harrison Marks, and the police corruption in Soho that allowed them to operate. Separately, these sources offer valuable tidbits of information about aspects of the British pornography business, but, collectively, they help to construct a timeline of when the industry came into existence and how it developed until the introduction of the R18 certificate in 2000, when the distribution of hardcore pornography in the United Kingdom was legalised, subject to classification, by the British Board of Film Classification ${ }^{1}$. However, these studies demonstrate that there has not yet been a sustained and deep engagement with the subject of the British hardcore business.

\section{Researching British Hardcore}

This article, and the edited Forum that follows considers how British hardcore business operates, joining historical and contemporary discourses. My own research specifically focuses on how the business emerged in the 1960s. In this period, I argue that the business operated as an alternative economy of cultural production. I use the term alternative economy to indicate how such a space operates outside of a formal economy, where the entrepreneurs within use new technologies to enable enterprise, exchange their artefacts for an economic benefit, and circumvent laws to allow their artefacts to be distributed. Colin Williams (2006) refers to such spaces as 'hidden enterprise cultures' and my own previous work has investigated alternative economies relating to forms of cult cinema (Carter, 2018). As part of this research, I have been particularly interested in how this economy of hardcore production was created and developed, focusing on the social, cultural, political and economic conditions of the 1960s.

Researching the business has proven to be challenging. The formative years trace back to the $1950 \mathrm{~s}$, and as the business operated in a clandestine manner, for reasons that will come apparent later in this article, it is difficult to track down those who were involved. Additionally, many of the producers and performers operate under different names, and some of the material discussing the industry is contradictory. This might explain why the studies discussed earlier lack depth. My own interest in the business came from reading a series of self-published autobiographies titled $I$ Pornographer by Michael Freeman (2011). The first book told seemingly fanciful stories about making pornography in the 1960s amongst a backdrop of police corruption and the London underworld. Upon closer inspection, and after consulting newspaper archives at the British Library, many elements of Freeman's stories were confirmed. I was able to track Freeman down, discovering that he was living in exile in Southern Italy. A series of on camera semi-structured interviews with Freeman were conducted in April 2016, with the intention of producing a documentary on his life, titled Hardcore Guaranteed (Simon Fletcher 2018).

These interviews form part of an ethnohistorical approach, which I have been using to historicise the British hardcore pornography business. According to Kuhn $(2002,6)$ ethnohistory can

\footnotetext{
${ }^{1}$ It should be acknowledged that there are a number of academic studies that discuss the introduction of the R18 certificate. See Hunter (2015), Petley (2011), and Perkins (2012).
} 
consist of "ethnographic description and interpretation alongside oral historical inquiry and the historians traditional source materials" (6). My own approach has included conducting semistructured interviews with those involved in the industry from the 1960 s to present day; at the time of writing, I have conducted 18 interviews. I attempt to interview with each participant a number of times, as Kuhn believes it helps build trust and allows time for past memories to be rediscovered. The majority of these have been with males, highlighting the gendering of production in the industry at that time, but also the difficulty of locating female performers who were involved in making pornographic films. Many of these performers are nameless, as no credits exist for any of films that were produced in the 1960s. In the rare instance when I have been able to locate past performers and contact them by email, I find that few are willing to talk, stating that they have moved on with their lives and do not wish to reconnect with their past. Conducting research in this area requires sensitivity, building of trust, and the use of "sponsors", who place me in contact with other potential interviewees (Walsh 2004, 31). The second part of my approach has involved archival research. This has included tracking down films on $8 \mathrm{~mm}$ and VHS formats, usually in a digitised form, articles from newspapers and magazines, such as $8 \mathrm{~mm}$ Magazine, Continental Film and Video Review, Video World, Late Night Video and Video $X$, and official records, which include birth and death certificates, and court cases. Collectively, these give an insight into how such films were produced and distributed, and "provide important corroboration, or may challenge, information received from informants" (Hammersley and Atkinson 2007, 122). It is also important to acknowledge the existence of online 'archives', which include the Vintage Erotica forum ${ }^{2}$, the Adult Loop Database ${ }^{3}$, and a range of blogs. These have proved to be an invaluable source for many of the materials I have located, as no formal archive currently exists for this specific material, which Dean, Ruszczycky and Squires (2014) note is a common issue for the porn scholar ${ }^{4}$. What follows is based on both the primary and secondary sources discussed thus far and seeks to give an insight into the conditions that led to introduction of an economy of British hardcore film production in the 1960s, and the practices of entrepreneurs who participated in the economy.

\section{The Glamour Film}

An early precursor to the rise in British hardcore production is the 'glamour film'. Chibnall (2003, 46) defines the glamour film as "three minute softcore reels featuring... models in states of undress". These short films were common in the late 1950s and early 1960s, and would feature short stripteases, much like those that could be found taking place live in the Soho strip clubs such as Paul Raymond's Revue Bar on Walker's Court, or the five clubs owned by Murray Goldstein ${ }^{5}$. Many of these films play on the reputation of Soho as a site for vice, with titles such as Soho Striptease (Pete Walker, 1960), labels such as Carnaby Kinks, and the film Down Town (Pete Walker, no date) containing footage of a woman walking through Soho to audition at what is seemingly a strip club. At this time, the key producers of glamour films were George Harrison Marks, Stanley Long ${ }^{6}$ and Pete Walker. A former vaudeville comedian, Walker started the label Heritage Films in 1958, producing and distributing glamour films. He would film them in less than an hour on a $16 \mathrm{~mm}$ camera and distribute them on the standard $8 \mathrm{~mm}$ format in cardboard boxes that would regularly feature a glamour style image of the starring model on the front. These were sold in Soho bookstores, shops selling photography equipment, and through mail order. According to Chibnall $(1998,35)$, Walker found

\footnotetext{
${ }^{2}$ http://vintage-erotica-forum.com/

${ }^{3}$ https://adultloopdb.nl

${ }^{4}$ According to Slade (1984), a collector donated a selection of British 'rollers' to the Kinsey Institute. My own research indicates that the Sexmuseum Amsterdam Venustempel also has a small holding of 1960s British pornography.

${ }^{5}$ Murray Goldstein's (2005) autobiography reflects on his career as a strip club owner in 1960s Soho, and gives a sense of the zeitgeist of this period.

${ }^{6}$ See Franklyn Wood (2017) and Long and Sheridan (2008), for more detail on Marks and Long's early careers as glamour photographers in Soho.
} 
this to be a highly profitable enterprise, issuing "one hundred a year" and "nearly four hundred by the time he sold the business" by the late 1960s. In a 2016 filmed interview found on the American Bluray release of For Men Only (Pete Walker 1967), Walker reflects on his glamour film past, stating that the films could command twice the cost price of a non-adult $8 \mathrm{~mm}$ films and would "sell ten times as many". He also acknowledges that the films were "taboo" at the time, but perfectly legal to make and distribute. Chibnall $(1998,37)$ believes that Walker's interest in the glamour market was solely financially motivated; he "could not resist the opportunity to exploit it". With the profit made from Heritage Films, Walker moved into making feature length $35 \mathrm{~mm}$ films for theatrical distribution. Though not the primary focus of my research, the glamour film phenomenon of the late 1950s and early 1960s can be seen as the forerunner of British hardcore filmmaking. It also highlights a number of changing cultural, political, economic, and technological factors that encouraged filmmakers to move beyond making softcore glamour films to films with hardcore content.

\section{A Permissive Turn?}

The first, and perhaps most significant, factor in the emergence of British hardcore production is the culture of the 1960s. A number of sources, both primary and secondary, indicate that London was a key player in the hardcore pornography business, despite it being illegal to distribute pornography in Britain at this time. Hebditch and Anning $(1988,212)$ state that "swinging London' of the 1960s was not just a consumer of 'foreign porn' but a major producer for European and Scandinavian markets". Initially I believed this could not be true, as Britain is not commonly mentioned as a forerunner of hardcore pornography, it appears that Britain was producing pornography on some scale for distribution in the UK, as well as exporting to foreign markets. But why did hardcore production develop in Britain in the 1960s? This is a question I have asked of all my interviewees, and they collectively respond to it by talking about how the 1960s saw a relaxation in morals that affected people's attitudes towards sex and sexuality. The term 'permissive society' is often used to describe this period, "when sexuality became a feature of public policy" and a common area of public discussion (Mort, 2010). Jeffrey Weeks $(1981,249)$ describes it as a:

“...legislative moment, producing a complex body of legislation passed in the decade after 1958, including reforms of the laws governing gambling, suicide, obscenity and censorship, Sunday entertainment, the abolition of capital punishment for murder, as well as liberalisation of various statutes governing sexual behaviour".

The term has become one of much contention, and regularly critiqued by scholars. Jeffrey Weeks (1981, 249), for instance, notes that the advocates for permissiveness would have rarely used the term, while conservative moralists tended to use it in an almost "scatological" manner. As demonstrated by the responses from my interviewees, it is often perceived that there were major changes to society at this time, but, as indicated by Mort $(2010,4)$ the "permissive society was neither a revolution in English social life nor a radical break with the sexual cultures that preceded it". For Mort, permissiveness is a far more complex concept that can be traced over a longer period of time, as restrictive policies and values introduced during Victorian remained in place. Therefore, for Mort (2010) and Weeks (1981), the 1960s was not as permissive as people have been led to believe.

However, during this period there were significant reformations to public policy during that directly related to sexual culture. For example, there was the Street Offences Act of 1959, the two amendments to the Obscene Publications Act in 1959 and 1964, the Sexual Offences Act of 1967, the Family Planning Act of 1967, the Abortion Act of 1967, legislation on divorce in 1969, and theatre censorship in 1969. Whilst these were not sweeping changes, and many might be considered problematic, as Mort (2010) and Weeks (1981) point out, I do not think it can be denied that this was a period of societal change. As Martin Tomkinson stated in an interview I conducted on the 22nd February 2017, the period saw a "loosening of the belt", meaning that attitudes were still repressive, but less so. In addition to legislation, there were also a number of key cultural events relating to 
sexuality during the period. The Profumo Affair was a highly sensationalised political sex scandal between 19 year old model Christine Keeler and a Member of Parliament named John Profumo that was regularly featured in the popular news from 1961 to 1963 . Mort $(2010,24)$ suggests that this news story "ensured that sexual London was advertised across the world", linking the political world of Westminster to the "sexual world" of Soho. The contraceptive pill was made available through the National Health Service in 1961. 'Nudist' films, such as George Harrison Marks' Naked as Nature Intended (1961) were passed for exhibition by the then British Board of Film Censors and shown in British cinemas. Finally, there was rise of other popular cultural forms, such as popular music; the term rock 'n' roll itself being a "sexual synonym" (Weeks 1981, 254). In combination with the aforementioned changes to legislation, these events also highlight that attitudes toward sex were becoming more relaxed in the 1960s. According to Mort $(2010,24)$ the West End of London, specifically Soho, became a symbol of permissiveness in the United Kingdom.

\section{The Dirty Square Mile}

Soho has long been synonymous with vice, and, according to Judith Summers $(1989,208)$, it is the most famous red-light district in London. The Soho of today has been heavily gentrified, and its criminal past is not immediately apparent. The area is known for its bohemian and cosmopolitan culture, traditionally being home to people from a range of nationalities. Aidan McManus, an interviewee who used to work in Soho's adult cinemas and now runs guided tours of Soho told me "no one comes from Soho, it doesn't discriminate, making it a place of tolerance" . It was also home to the UK's growing film industry, with "British film production offices, post-production facilities, and distribution companies" located on Wardour Street (Summers 1989, 180). Alongside the film production taking place in Soho was a shadow industry of porn production. According to Mort (2010) Soho was the central location for London's sexual economy, with pornography and sex work being its defining feature. This economy was able to operate through an alliance between local entrepreneurs and the Metropolitan Police. Amongst these local entrepreneurs were strip club owners Paul Raymond and Murray Goldstein, bookstore owner Jimmy Humphreys, and Bernie Silver, a pimp and "flat farmer'8 who was known as the "godfather of Soho" (Summers 1989, 212). From the 1940s onwards, the London's underworld had more control over the activities in Soho than the Metropolitan police, starting with the Messina Brothers, who consolidated vice in Soho through often brutal methods (Summers 1989, 211). Though only a square mile in total, Soho's narrow streets made it an ideal contained space for criminal activity, and a difficult space to police. Instead the police relied on 'working' with criminals, such as Bernie Silver, and his associate Frank Mifsud, to 'manage' Soho.

Bookstores, early examples of sex shops, were spaces were pornographers could sell their products. Mike Freeman, a pornographer who started operating in the early 1960s, sold photographs in sets of five to the bookstores 9 . These would be sold on by the owners in the backrooms of their shop for high profits; legally acceptable softcore material would be sold in the front of the shop (Manchester 1986, 30). Under British law, distributing hardcore pornography was restricted by the Obscene Publications Act ${ }^{10}$. This was introduced to "strengthen the law concerning pornography" (Robertson 1979, 20). The vague and problematic law was enforced by the Obscene Publications Squad (OPS), an arm of the Metropolitan Police known as the Dirty Squad. According to Geoffrey Robertson $(1979,5)$ OPS officers "maintained an unofficial licensing system in Soho, permitting the surreptitious sale of hardcore material". OPS officers found that they could make large sums of money from those involved in Soho's sexual economy as well as controlling what could or could not be sold in the bookstores. Martin Tomkinson (1980, 53-54) states that the "going rate" for a licence would

\footnotetext{
${ }^{7}$ Aidan McManus was interviewed on the 8 June 2016.

${ }^{8}$ Flat farming was a highly exploitative practice that involved landlords letting flats to sex workers at high rents.

${ }_{9}^{9}$ All information relating to Mike Freeman is taken from interviews conducted between April 3rd and 6th, 2016, and the first volume of his autobiography (Freeman, 2011).

${ }^{10}$ A detailed history of British obscenity law can be found in Robertson (1979).
} 
be " $£ 100$ - $£ 200$ for a single shop"; larger players like Jimmy Humphreys would pay $£ 1000$ a month. People who would not pay for a license, or broke the rules of their licence, would have their premises raided and be arrested. This was one of the many intimidatory tactics employed by the OPS to control the distribution of pornography in Soho. With these informal 'rules of trade' in place, Soho would become the marketplace for distributing hardcore pornography. German pornographer Hans Moser (cited in Hebditch and Anning 1988, 212) said that industrial production of hardcore "porn started in Soho, not in Sweden or Denmark as many believe", as pornography was not fully legalised in Denmark until 1969, and 1971 in Sweden ${ }^{11}$. However, increased access to film making technologies would also play an important part in the development of British hardcore pornography.

\section{Film Technology}

The introduction of new technologies can always present opportunities for enterprise, and in the context of British hardcore production, are worth briefly exploring here. In the late $1950 \mathrm{~s}, 35 \mathrm{~mm}$ film making was the dominant, professional mode of production. This was, and remains, a costly pursuit that is not easily accessible to the amateur film maker. Eric Schaefer $(2002,7)$ notes how "companies such as Kodak and Bell and Howell marketed the $16 \mathrm{~mm}$ gauge as a leisure product for middle- and upper-middle-class families" from the late 1920s onwards. In the $1950 \mathrm{~s}, 8 \mathrm{~mm}$ emerged as an affordable format for amateurs, and " $16 \mathrm{~mm}$ came to be considered a semi-professional - but still a nontheatrical-gauge" (ibid). As amateur film making equipment became increasingly available, "a national culture of amateur cine-clubs" were established across Britain, alongside a number of magazines devoted to the subject, such as $8 \mathrm{~mm}$ Magazine and Amateur Cine World (Reekie 2007, 104). Enthusiasts interested in learning how to use the technology could participate in these clubs, giving them access to the equipment and a like-minded community. This had two implications for the making of hardcore pornography. Firstly, the affordability of the cameras increased accessibility, and, secondly the domestic use of $8 \mathrm{~mm}$ meant that projectors would become a feature in middle-class homes $^{12}$. Slade (1984) recognises the importance of the $8 \mathrm{~mm}$ format in reviving the pornographic stag film at the start of the 1960s. Prior to this, viewings of hardcore pornography in Britain would often be confined to a "private screening at a stag party or similar single-sex gathering" (Chibnall $2003,45)^{13}$. With $8 \mathrm{~mm}$ it now became possible to watch films in the privacy of the home, providing that you were able to afford the equipment.

According to Chibnall $(2003,46)$ the glamour film business had demonstrated that there was a market for adult content, and as competition amongst glamour film makers grew, others began to differentiate by making hardcore pornography. The early British hardcore 'rollers' ${ }^{14}$ first appear in the mid-1960s, being shot on either $8 \mathrm{~mm}$ or $16 \mathrm{~mm}$ cameras, with no sound, and primarily distributed on $200 \mathrm{ft}$ black and white standard $8 \mathrm{~mm}$ film ${ }^{15}$. To develop the films, film makers had to be creative, as film laboratories would not usually be receptive to developing potentially obscene content; unless an employee could be persuaded with money or intimidation. Freeman would eventually start his own laboratory, importing developing and printing equipment from the United States, finding it frustrating, and risky, to locate amenable local processing labs. The early producers of hardcore tended to have backgrounds in photography and were able to transfer their experience of using still cameras to $16 \mathrm{~mm}$ film making cameras. Having identified the conditions for the emergence of British

\footnotetext{
${ }^{11}$ See Taylor (1970).

${ }^{12} 8 \mathrm{~mm}$ cameras and projectors were regularly advertised in the back pages of tabloid newspapers throughout the 1960 s.

${ }^{13}$ An article from News of the World, February 5 1967, tells of 'blue films' being screened in at The Regent Palace Hotel in Piccadilly Circus.

${ }^{14}$ According to Mike Freeman, British hardcore porn films were known as 'rollers' rather than loops, because of how the $8 \mathrm{~mm}$ reels would roll when projected.

${ }^{15}$ Di Lauro and Rabkin (1976) estimate that the British hardcore rollers first appeared between 1964 and 1966.
} 
hardcore I now move on to discuss how two film makers operated within this alternative economy of production, using technology and circumventing imposed rules and regulations.

\section{The "gentleman" Ivor Cook}

In much of the literature that does exist on British hardcore film, Ivor Cook ${ }^{16}$ is regularly identified as being an important figure in the development of an economy. Thompson $(2007,224)$ states that Cook was the "brilliant eye whose "Climax Films Present" trademark precedes some of the most exquisitely realised British stags ever made". However, little is known about Cooke, which is unsurprising considering that the films were made in such clandestine circumstances. From my own research, it appears that Cook was the first person in Britain to produce hardcore pornography and distribute it through a branded label: Climax. Interviewees who either worked with Cook or knew of him, such as Mike Freeman, Dave Wells ${ }^{17}$ and Lindsay Honey ${ }^{18}$, have told me that Cook was born in 1927, lived in Surrey, and was initially a respected glamour photographer. He is remembered as a "gentleman" or a "sweet man", and unlike many of the other characters operating in Soho during the 1960s. For example, Moser (cited in Hebditch and Anning 1988, 213) recalls Cook as being "a real gentleman in all the other shit", referring to the corruption taking place in Soho at the time when Cook was producing films. It appears that Cook started making films to distribute on his Climax label in 1963 or 1964. In literature, Cook is linked to a roller titled $100 \%$ Lust, that allegedly features Christine Keeler of the Profumo Affair in a hardcore scene (Hebditch and Anning 1988, Flint 1999, Thompson 2007, McGillivray 2017). As Al Di Lauro and Gerald Rabkin (1976) recognise, there are many early stags purported to star Hollywood actresses, or other celebrities, but these are usually nothing more than an exploitation marketing technique to sell the films. The actress in 100\% Lust is not Christine Keeler, but the linkage of her to this film further strengthens Mort's (2010) claim that the Profumo Affair was a key moment in changing attitudes towards sex.

Cook seems to have shot his films on the semi-professional gauge of $16 \mathrm{~mm}$, distributing them on $200 \mathrm{ft} 8 \mathrm{~mm}$ film, with a running time of around 15 minutes. Distributing on $8 \mathrm{~mm}$ was both a practical and a commercial decision. The films would be consumed domestically by those who owned an $8 \mathrm{~mm}$ projector. According to Freeman, Cook's early films were presented in generic white boxes with a lurid photographic image glued to the front; this way usually a still taken from the film with the film's title printed onto the image. In terms of distribution, they could be purchased in the back rooms of Soho's bookstores for around $£ 10$ each (the equivalent of $£ 185$ today, after inflation) ${ }^{19}$, and through mail order. The Post Offices Act of 1953 made the distribution of 'indecent' material through the postal service a criminal offence. Freeman talks about the OPS warning him to not distribute through mail order, as they would have little control of where the pornography might be sold to. Keeping the distribution of pornography in Soho gave OPS an awareness of who was producing content, and a way to control production. Reekie $(2010,105)$ identifies that the "back pages of cine magazines became increasingly peppered with adverts for soft porn marketed as glamour films or later adult films". From looking at a selection of back pages of $8 \mathrm{~mm}$ Magazine, Continental Film Review and Cinema $X$, glamour films are openly advertised, but there are also carefully worded adverts that imply the sale of harder content:

“"'IT'S A CATCH” How many times have you seen an advertisement and said that? Did you know that the publishers take steps to ensure that you don't get caught. Our customers don't get caught either, far from it. We sell brand new 24/- $8 \mathrm{~mm}$. Movies for half price. Why not send 12/- for a sample. $£ 2$ for colour sample. Complete list of all titles free on application."

\footnotetext{
${ }^{16}$ Ivor Cooke is referred to

${ }^{17}$ Interview with Dave Wells conducted on 28th October, 2017

${ }^{18}$ Interview with Lindsay Honey conducted on 12 September, 2017.

${ }^{19}$ The Longford Report (1972) and Cox, Shirley and Short(1977) give an insight into the financial aspects of Soho's the pornography trade.
} 
Such adverts were intended to deflect attention away from the selling of hardcore content. Freeman remembers advertising the sale of glamour films in similar publications, and, once a purchase was made, he would send a catalogue of hardcore films to the customer. These examples show some of the ways producers, and distributers, attempted to circumvent the laws of the time.

Cook also exported his Climax productions to Scandinavia, specifically Denmark, taking British porn out of Soho and to Europe. To achieve this, he utilised the services of Walter Bartowski. According to Hebditch and Anning (1988, 212-213), Bartowski, also known as 'Charlie Brown', was a German-Polish prisoner-of-war during World War Two. Following the war, Bartowski remained in the UK, and worked as a steward on cross channel ferries between Britain and Scandinavia. Bartowski became Soho's "top porn smuggler", handling "slides [photographs], picture sets and 8mm black and white films" (ibid). In 1966, six of Cook's films were purchased by Jens and Peter Theander, and sold in their bookstore 'Rådhusantikvariatet', located on Studiestræde 17, in Copenhagen, Denmark. This shop opened in 1966, when it was illegal to distribute pornography in Denmark. Though the shop windows would display innocuous material, harder products were available "under the counter" (Hebditch and Anning 1988, 54). In addition to hardcore magazines, the Theanders sold Ivor Cook's Climax rollers. In 1967, written pornography became legalised in Denmark, and the brothers moved into production, publishing a magazine named Color Climax; the title being inspired by Cook's films. A police crackdown on pornography in 1967 put many of the Theander's competitors out of business, but, fortuitously, they were not raided. They continued to license and sell Cook's films before making their own films in 1968, drawing inspiration from his work. In 1969, once all pornography was legalised in Denmark, the Theanders professionalised and upscaled their production, purchasing a film laboratory they named Rodox. Now having the means to produce and distribute their films, the Theander brothers focused on quality to distinguish themselves from the standard black and white rollers. The Color Climax Corporation was born and became a successful "international commodity" (Heffernan 2016, 130). Anglophone histories of Scandinavian porn tend to neglect the role British hardcore production played in the development of the Danish porn industry (see Stevenson 2010 as an example). It appears that the brand Climax was introduced by Cook and later adopted by the Theanders in recognition of his $8 \mathrm{~mm}$ films. Danish bloggers also acknowledge Cooke as being a pioneer in his production style, and representation of sexual acts, such as double penetration ${ }^{20}$.

It is not clear how many films Cook made, as he was not the only producer to use the Climax brand in the United Kingdom. Freeman describes Cook as "brilliant, but infrequent" filmmaker, being more prolific as a glamour photographer. It seems that Cooke stopped making films around 1970. According to producer and performer Dave Wells, Cook was still heavily involved in producing pornography, being the senior photographer for Berth Milton Senior's Private Media Group, who were responsible for publishing the first colour hardcore pornography magazine in Sweden, 1965. It would appear that Cook's reputation as a pornographer led to this appointment. Cook died of a heart attack in 1985.

\section{The Entrepreneur - Michael J Freeman}

The work of Cook inspired another London based photographer to move into hardcore film production. Freeman was born Michael John Muldoon in Vauxhall, London, 1938. A petty criminal from a young age, Freeman had an early interest in art, which manifested itself in the erotic drawings he would produce to sell to his school friends, and, eventually, Soho sex shops. Freeman moved quickly from taking glamour photographs of his wife Sandra, and their friends, to taking hardcore photographs and, by the mid 1960s, he was producing hardcore films and distributing them on $8 \mathrm{~mm}$. Conversations with Freeman reveal that he had aspirations to be a legitimate businessman. As he

\footnotetext{
${ }^{20} \mathrm{See}$ http://climaxstory.com/ and http://www.hmpmovie.dk/ for more information about the development of the Danish porn industry, as well as Nordstrøm (2012).
} 
began to make money from selling his photographs to the Soho bookstores he registered a company named Nestville Photography with Companies House; intentionally choosing a bland, generic name to front his pornography business. As Freeman's photographs became increasingly popular, a Soho bookstore owner recommended that he contact the OPS to apply for a licence. His background as a petty criminal had given Freeman a mistrust of the police, so he refused. A week later, he found that Soho shops were no longer purchasing his photographs. To resolve this problem, Freeman employed a front man named Evan 'Big Jeff' Phillips to sell the photographs to bookstores. Eventually, the OPS arrested Freeman in 1966 for making and profiting from an obscene publication under the Obscene Publications Act. Freeman spent 18 months in prison, but immediately returned to the pornography business upon on his release. While in prison, Phillips became a pornographer in his own right, paying the OPS for a licence to trade, and quickly profiting from the demand for hardcore content that Ivor Cook had helped create.

Upon release from prison, Freeman visited the now wealthy Phillips and pressured him into giving money to restart his business. Not wanting trouble, Phillips agreed, and advised Freeman to buy a license from OPS, offering to setup a meeting with the head of the OPS Chief Inspector Leslie Alton. Freeman states that his license had the following conditions: no mail-order, no export, no underage models, and to provide a copy of every film, and set of photos, he produced. Freeman told me that the cost of the license was $25 \%$ of his monthly earnings. Now licensed, Freeman began to shoot in colour, having purchased a $16 \mathrm{~mm}$ wind-up Bolex camera, and was beginning to experiment using sound for his productions; most $8 \mathrm{~mm}$ productions were silent. He also upscaled production, investing profit from the films and photographs into leasing a factory in the East End of London. This factory would become Freeman's own film laboratory, where he printed and duplicated his own films, having purchased two 16mm Uhler branded optical printers from Michigan, USA. Freeman regards himself as an entrepreneur, and his practices indicate a business acumen. For example, as a cost saving measure, he would purchase $16 \mathrm{~mm}$ film photography shop and split the film himself to make it $8 \mathrm{~mm}$ gauge. Also, unlike Cooke, Freeman released films on four labels: Action, Eros Films, Venus Films and Climax Films. The latter two brand choices were based on other successful labels, Russell Gay's Venus Films, which released glamour films, and Cook's Climax. As none of these brands were oficially registered, and the economy was unregulated with no regard for intellectual property rights, Freeman used the familiarity with these established brand names to increase sales. Freeman told me that he went as far as registering the brand Climax in the UK, though I have not been able to find evidence to support this claim. Freeman sold his films to Soho bookstores for $£ 5$, who would then sell them for around $£ 16$, making anywhere between $£ 400$ to $£ 2000$ a week; a considerable amount of money in the late 1960s. He then branched out into making 'Soho Typescripts': erotic books illustrated with photographs, diversifying his production.

Wanting to increase profits further, Freeman broke his license, firstly by selling through mail order, and exporting to Amsterdam. Through exporting to Amsterdam, where it was legal to distribute porn, Freeman could earn around $£ 1000$ per delivery. After several successful flights to Amsterdam smuggling pornography in suitcases, he was arrested and imprisoned for six weeks. At this point, Freeman believes that a contract on life was arranged by Alton for breach of license. Through another detective in the OPS, Freeman learned that Alton preferred working with the more compliant Evan Phillips, and saw Freeman as being uncontrollable and volatile. Fearing for his life, Freeman employed a minder named Gerald Hawley, who he had met in prison when serving time for the Obscene Publications Act offence. Hawley was a former enforcer for East End gangsters the Kray twins, and a regular actor in Freeman's films. According to John Pearson $(2015,250)$ the Krays had an interest in Soho's pornography business, providing protection to distributors and wholesalers who were importing pornography from Europe. Learning of the Krays' involvement with the Soho porn economy, Freeman became concerned that they would be the ones hired to the deliver the 'hit' on his life. When the Krays were imprisoned in 1968, and no attempt had yet been made on his life, Freeman believed that the contract was now terminated. On the evening of May 21st, 1969, Hawley turned up unannounced at Freeman's house, and attempted to murder him. Freeman, and his brother-in-law Kenneth Eighteen, were able to resist Hawley, stabbing him 89 times. Eventually, Freeman and 
Eighteen were arrested for the murder of Hawley, the crime being reported in the British tabloid press $^{21}$. Though Freeman argued that he had acted in self defence, he was imprisoned for ten years on a charge of manslaughter. Freeman's brief involvement in this early economy of hardcore porn production was relatively short and interrupted by spells in prison. However, during this period of time, he was able to professionalise his production and make a considerable amount of money out of hardcore production, but found himself unable to comply with the terms set by the OPS. Upon release from prison in 1979, Freeman started the company Videx, becoming the first person to produce and distribute hardcore pornography on video tape in Britain. In 1980, he made Britain's first full length hardcore feature Truth or Dare (Mike Freeman, 1980). He would again be imprisoned under the Obscene Publications Act in 1983, and Freeman now lives in exile in southern Italy, having breached the terms of his life license for murdering Hawley.

\section{The Climax}

Cook and Freeman's practices give an insight into how the British hardcore pornography business emerged and operated in Soho in the 1960s. Through using new film making technologies, and circumventing obscenity laws that rendered the distribution of hardcore pornography legally contentious, both were able to make significant amounts of money from their enterprise. Whilst it is questionable how permissive the 1960s were, a number of social, economic and cultural developments brought sexuality into public consciousness. These were financially exploited by Cook and Freeman and, through their film making, they inadvertently created an alternative economy of hardcore production Britain, finding ways to navigate obscenity law. The potential high profits from making pornography attracted other filmmakers, such as Evan 'Big Jeff' Phillips. A former accountant, Phillips began as a protégé of Freeman, before moving producing hardcore rollers in 1966. Recognising the value of Cook's Climax brand, Phillips started the label Climax Original, also known as Original Climax Films, with an initial investment of $£ 350$. Phillips had the means to produce films on a higher scale. Unlike Cook and Freeman, whose pornography businesses remained relatively unknown, Phillips appeared to court fame, leading a very lavish, excessive lifestyle and mixing with the celebrities of the day. This led to an exposé by Sunday People tabloid newspaper, who, over the course of several weeks in February 1972, revealed the thriving pornography business in Soho, and named Phillips as Britain's "first blue millionaire". At this point, a number of other labels had emerged, such as Academy Films, Anglo Continental Films, Blue Scene Films, Universal Films and Viking Films. These sought to benefit from the demand for hardcore pornography in Britain, and Europe where pornography was now legal to distribute.

On the $6^{\text {th }}$ February, a Sunday People article reported that Phillips had started a company named Original Climax Films A.S in Copenhagen, Denmark, in collaboration with Walter Bartowski; the porn smuggler known as Charlie Brown. With pornography now fully legalised in Denmark, Phillips moved his operation there, and smuggled his films back into the UK using planes, boats and refrigerated lorries. The article states that "in two years Phillips had made enormous profits from the sale of his films. For the retail price has always been eight or nine times the cost of production". By 1971, the company was "declared financially insolvent". At the height of his success, Phillips was earning $£ 50,000$ a week, but by 1974, Phillips' business came to an end when he was raided and arrested for "conspiracy under the Obscene Publications Act". On May 18th 1975, the Sunday Mirror announced Phillips' death at the age of 33; he had committed suicide. Two weeks before his death, Phillips had met with journalists from the tabloid, and informed them of the corruption taking place in Soho. But Scotland Yard was already aware of the OPS's activities from the work of the Sunday People in 1972. As a response, the Metropolitan Police appointed Robert Mark as Commissioner, and set him with the task to root out corruption. The investigation revealed the relationship between the OPS, the London underworld, and Soho's pornographers, which led to the prosecution of a number

\footnotetext{
${ }^{21}$ See The News of the World, December 21st, 1969.
} 
of members of the OPS ${ }^{22}$. This removed the unofficial licensing system that had taken place in Soho, closing the loophole that had allowed the British pornography business to grow with support from the police.

Despite this major intervention, hardcore pornography was still being distributed in Soho and across Britain. With Phillips dead, Freeman in prison, and Cook seemingly no longer producing, Scotsman John Lindsay entered the economy, making numerous films and opening cinema clubs in Soho that screened hardcore pornography. According to David Kerekes $(2000,196)$, Lindsay used "a loophole in British law that allowed private, members-only clubs to fall outside of the BBFC and the Obscene Publications Act", again highlighting the entrepreneurial mindset of the British hardcore pornographers. Through his Taboo and Karl Ordinez brands, Lindsay produced and distributed hard pornographic rollers, and screened them in his cinemas. Filming in colour and with sound, Lindsay escaped repeated attempts at obscenity, and used this notoriety to promote his films. By this time, hardcore pornographic production was firmly established, the main players being Color Climax in Denmark, the Swedish company Private, Beate Uhse in Germany, and the American business was prospering (Heffernan, 2015). The research I have presented here indicates that Freeman and Cook had contributed to this expansion of hardcore film making. A search for the word Climax on the Adult Loop Database shows that 25 labels have used the word 'climax' in their branding ${ }^{23}$. This demonstrates how universal the brand Climax brand has become, from its early beginnings in Soho where entrepreneurs such as Ivor Cook, Mike Freeman, and Evan Phillips, made 'original' Climax films.

\section{Acknowledgements}

The author would like to thank Simon Fletcher, Mike Freeman, Edward Goodman and JJ Marsh of the Erotic Film Society for their contributions to this article.

\footnotetext{
${ }^{22}$ A full account of this investigation can be found in Cox, Shirley and Short (1977) and Tomkinson (1982).

${ }^{23}$ https://adultloopdb.nl
} 


\section{References}

Alilunas, P. 2014. The Necessary Future of Adult Media Industry Studies. Creative Industries Journal 7, no 1: 62-66.

Alilunas, P. 2016. Smutty Little Movies: The Creation and Regulation of Adult Video. California: University of California Press.

Carter, O. 2018. Making European Cult Cinema: Fan Enterprise in an Alternative Economy. Amsterdam: Amsterdam University Press.

Chibnall, S. 1998. Making Mischief: The Cult Films of Pete Walker. Surrey: FAB Press.

Chibnall, S. 2003. Get Carter. London: I.B Tauris.

Church, D. 2016. Disposable Passions: Vintage Pornography and the Material Legacies of Adult Cinema. London: Bloomsbury.

Cox, B., J. Shirley and M. Short. 1977. The Fall of Scotland Yard. Middlesex: Penguin.

Dean, T., S. Ruszczycky and D.D.E. Squires. 2014. Porn Archives. London: Duke University Press.

Di Lauro, A. and G. Rabkin. 1976. Dirty Movies: An Illustrated History of the Stag Film, 1915-1970. New York: Random House Value.

Fenton, H. ed. 2000. Flesh and Blood Compendium. Surrey: FAB Press.

Flint, D. 1999. Babylon Blue: An Illustrated History of Adult Cinema. London: Creation Books.

Freeman, M.J. 2011. I Pornographer. Online: Amazon.

Goldstein, M. 2005. Naked Jungle. London: Silverback Press.

Grant, C. and A. Kuhn. 2006. Screening World Cinema : A Screen Reader. London ; New York: Routledge. Table of contents only http://www.loc.gov/catdir/toc/ecip061/2005029278.html

Publisher description http://www.loc.gov/catdir/enhancements/fy0654/2005029278-d.html

Hammersley, M. and P. Atkinson. 2007. Ethnography: Principles in Practice. London: Routledge.

Hebditch, D. and N. Anning. 1988. Porn Gold: Inside the Pornography Business. London: Faber and Faber.

Heffernan, K. 2015. Seen as a Business: Adult Film's Historical Framework and Foundations. In New Views on Pornography: Sexuality, Politics, and the Law, eds. Comella, L and Tarrant, S, 37-56. California: Praeger.

Heffernan, K. 2016. From "Sex Entertainment for the Whole Family" to Mature Pictures: I Jomfruens Tegn and Transnational Erotic Cinema. In Grindhouse: Cultural Exchange on 42nd Street, and Beyond eds Fisher, A and Walker, J, 129-44. London: Bloomsbury.

Hunter, I.Q. 2013. British Trash Cinema. London: Palgrave MacMillan.

Hunter, I.Q. 2014. Naughty Realism: The Britishness of British Hardcore. Journal of British Cinema and Television 11, no 2-3: 152-71.

Kerekes, D. 2000. Jolly Hockey Sticks! In Fleshpot: Cinema's Sexual Myth Makers and Taboo Breakers ed. Stevenson, J. Manchester: Headpress.

Kuhn, A. 2002. Everyday Magic: Cinema and Cultural Memory. London: I.B Tauris.

Larsson, M. 2016. The Swedish Porn Scene: Exhibition Contexts, 8mm Pornography and the Sex Film. Chicago: University of Chicago Press.

Long, S. and S. Sheridan. 2008. X-Rated: Adventures of an Exploitation Filmmaker. London: Reynolds \& Hearn.

Maina, G. and F. Zecca. 2014. Successive Slidings of Pleasure: The Birth of Italian Porn. Paper presented at the XII MAGIS International Film Studies Spring School, in Gorizia, Italy.

Manchester, C. 1986. Sex Shops and the Law. Hampshire: Gower.

McGillivray, D. 2017. Doing Rude Things. London: Wolfbait.

Mort, F. 2010. Capital Affairs: London and the Making of the Permissive Society. London: Yale University Press.

Nordstrøm, J. 2012. Danish Porn. Copenhagen: Nordstroms.

Pearson, J. 2015. The Profession of Violence: The Rise and Fall of the Kray Twins. London: William Collins.

Perkins, M. 2012. Pornography, Policing and Censorship. In Policing Sex, eds. Johnson, P and Dalton, D, 
85-98. London: Routledge.

Petley, J. 2011. Film and Video Censorship in Contemporary Britain. Edinburgh: Edinburgh University Press.

Pornography: The Longford Report. 1972. London: Coronet.

Reekie, D. 2007. Subversion: The Definitive History of Underground Cinema. London: Wallflower.

Robertson, G. 1979. Obscenity. London: Weidenfeld and Nicolson.

Schaefer, E. 2002. Gauging a Revolution: 16mm Film and the Rise of the Pornographic Feature. Cinema Journal 41, no 3: 3-26.

Sheridan, S. 2005. Keeping the British End Up: Four Decades of Saucy Cinema. Richmond: Reynolds \& Hearn.

Slade, J.W. 1984. Violence in the Hardcore Pornographic Film: A Historical Survey. Journal of Communication 34, no 3: 148-63.

Stevenson, J. 2010. Scandinavia Blue: The Erotic Cinema of Sweden and Denmark in the 1960s and 1970s. North Carolina: McFarland \& Company.

Summers, J. 1989. Soho: A History of London's Most Colourful Neighbourhood. London: Bloomsbury.

Tarrant, S. 2016. The Pornography Industry: What Everyone Needs to Know. Oxford: Oxford University Press.

Taylor, L.S. 1970. Decision in Denmark: The Legalizing of Pornography. California: Academy Press.

Thompson, D. 2007. Black and White and Blue Adult Cinema from the Victorian Age to the VCR. Toronto: ECW Press.

Tomkinson, M. 1982. The Pornbrokers: The Rise of the Soho Sex Barons. London: Virgin.

Walsh, D. 2004. Doing Ethnography. In Researching Society and Culture, ed. Seale, C, 225-37. London: Sage.

Weeks, J. 1989. Sex, Politics and Society: The Regulation of Sexuality since 1800. London: Longman.

Williams, C. 2006. The Hidden Enterprise Culture: Entrepreneurship in the Underground Economy. Cheltenham: Edward Elgar. Table of contents http://www.loc.gov/catdir/toc/ecip068/2006005603.html

Wood, F. 2017. The Naked Truth About Harrison Marks. London: Wolfbait. 